\title{
Demografien, \\ den økonomiske krise \\ og sundhedsvæsenet
}

\author{
Kjeld Møller Pedersen \\ professor i sundhedsøkonomi og -politik, Syddansk Universitet
}

Den demografiske udvikling og fortsat mervækst ud over vækstrate for BNP kræver frem til 2020 en vækst i sundhedsudgifterne på 4-5 mia. kroner per år. Den økonomiske krise har i 2012 reduceret den årlige vækst til godt 1 mia. kr. per år. Der er ikke udviklet en sammenhængende strategi for løsning af dette misforhold med fare for et kommende opdæmmet udgiftsbehov. Elementer af allerede igangsatte tiltag er: Øget produktivitet, bedre kvalitet med omkostningsbesparelser, reduceret aktivitet ved hjælp af indikationsprioritering og en mere effektiv kommunal indsats. Der er ikke p.t. planer om gennemgribende reformer. Brugebetaling på lægebesøg og flere private sygeforsikringer løser langt fra finansieringsproblemet.

\section{Indledning}

Vi har vidst det længe: Den demografiske udvikling med en aldrende befolkning og forlænget levetid er en økonomisk og organisatorisk udfordring for sundhedsvæsenet. Den økonomiske krise ramte med uforudset og uventet styrke i 2008-09 og er fortsat en ubehagelig realitet.

Grundlæggende er problemerne relativt lette at overskue: Den aldrende befolkning kombineret med stigende middellevetid er ressourcekrævende. Hertil kommer, at aldersgruppen 15-64-årige falder. Det er et dobbeltpres: Øgede udgifter i social- og sundhedssektoren og pres på skattegrundlaget blandt de erhvervsaktive. Hertil skal så føjes konsekvenserne af den økonomiske krise med faldende vækst, øget arbejdsløshed, krise i den finansielle sektor og pres på statsfinanserne, som i skattefinansierede sundhedsvæsener smitter direkte af i form af mindre vækst eller direkte faldende bevillinger til sundhedsvæsenet. Det er mindre let at se klare løsningsstrategier for sundhedsvæsenet for disse udfordringer.

Indledningsvis redegøres der for problemets omfang og karakter, dvs. den demografiske udvikling og de isolerede økonomiske konsekvenser heraf. De langsigtede prognoser frem mod 2040 gennemgås ret detaljeret for bl.a. at indkredse deres pålidelighed og dermed det grundlag, der kan planlægges på. Dette sammenkobles dernæst med konsekvenserne af den økonomiske krise i form af et abrupt fald i væksten i sundhedsudgifterne og langsom genopretning. Dette følges af et afsnit med forskellige løsningsstrategier, der enten allerede er taget i brug eller er under udfoldning.

\section{Problemets omfang}

Analytisk består udfordringen i at forstå konsekvenserne af den demografiske udvikling uafhængigt af den økonomiske krise. Velfærdskommissionens slutrapport og de tekniske analyser ${ }^{1,2}$ udkom, før den verdensomfattende krise meldte sig - ja nærmest på toppen af en højkonjunktur - og kan derfor bruges som eksempel på en vurdering af situationen før krisen sammen med Det økonomiske Råds forårsrapport fra 2000. Efterårsrapporten 2009 fra Det økonomiske Råds formandskab ${ }^{3}$ ligger, før konsekvenserne af krisen for alvor slog igennem, medens Løkke Rasmussen-regeringens Genopretningspakke ${ }^{4}$ og Thorning-Schmidt-regeringens 2020-plan ${ }^{5}$ tegner konsekvenserne af krisen. Det er med disse dokumenter som afsæt, at udfordringens omfang indkredses i nærværende artikel.

Grundideen bag fremskrivningen af fremtidens sundhedsudgifter er simpel på det konceptuelle plan, men vanskelig i praksis, bl.a. fordi de indbyggede antagelser om fx dødelighed og udvikling i middellevetiden over 30 - 
50 år betyder meget. Ifølge OECD er der udviklet mindst 25 modeller af varierende kompleksitet. ${ }^{18}$

Ingredienserne i de fleste modeller er: En befolkningsprognose, en aldersfordelt profil for brugen af sundhedsydelser, antagelse om forbrug af sundhedsydelser i de sidste leveår ('terminaludgifter', 'sund aldring'), antagelser om produktivitetsudviklingen og ændret teknologi (nye behandlingsmetoder). Hertil kommer en antagelse om sammenhængen mellem den økonomiske udvikling - udtrykt ved væksten i bruttonationalproduktet - og restvæksten i sundhedsudgifterne, dvs. det der ligger ud over den demografiske udvikling. 'Restvæksten' tænkes i praksis at indfange bl.a. ændret teknologi. I Danmark er disse fremskrivninger en del af de løbende langtidsprognoser baseret på DREAM-modellen (Danish Rational Economic Agent). ${ }^{19}$ Gennemgangen i det følgende er trinvis svarende til de ovenfor nævnte ingredienser i de fleste modeller.

Da policy-tiltagene skal være afstemt efter problemets omfang og styrke, er prognoserne pålidelighed af afgørende vigtighed.

\section{Den demografiske udvikling}

Den demografiske udvikling fra 2012 til 2040 er sammenfattet $i$ tabel 1 . Antallet af personer over 64 år stiger med over 500.000, og undergruppen af de over 80 -årige stiger nærmest eksplosivt. Samtidig falder antal personer i aldersgruppen 15-64 år med godt 100.000.

Tabel 1: Befolkningsudviklingen 2012-2040

\begin{tabular}{|l|c|c|c|}
\hline & $\begin{array}{c}\text { Antal 2012, } \\
\text { 1000er }\end{array}$ & $\begin{array}{c}\text { Antal 2040, } \\
\text { 1000er }\end{array}$ & $\begin{array}{c}\text { \% ændring } \\
\mathbf{2 0 1 2 - 2 0 4 0}\end{array}$ \\
\hline 0-14 år & 990 & 1047 & $6 \%$ \\
\hline 15-64 år & 3631 & 3519 & $-3 \%$ \\
\hline 65+årige i alt & 967 & 1474 & $52 \%$ \\
\hline Heraf 80+årige & 230 & 472 & 105 \\
\hline
\end{tabular}

Kilde: DREAM ${ }^{20}$

Middellevetiden for nul-årige øges med næsten 5 år frem mod 2040, og restlevetiden for 60-årige øges med tæt på 3,5 år, tabel 2. I DREAM er stigningen i fremskrivningen af den aldersbetingede restlevetid for fx 60-årige en forlængelse af de seneste års udvikling kombineret med en tendens til gradvist aftagende vækst.

Tabel 2: Udviklingen i middel- og restlevetiden 2012-2040

\begin{tabular}{|c|c|c|c|}
\hline $\begin{array}{c}\text { Middellevetid, } \\
\text { 2012, 0-årige }\end{array}$ & $\begin{array}{c}\text { Middellevetid } \\
\text { 2040, 0-årige }\end{array}$ & $\begin{array}{c}\text { Restlevetid, } \\
\mathbf{2 0 1 2} \mathbf{6 0} \text { årige, }\end{array}$ & $\begin{array}{c}\text { Restlevetid, } \\
\text { 2040, 60 årige, }\end{array}$ \\
\hline 79,6 & 84,2 & 22,5 & 25,9 \\
\hline
\end{tabular}

Kilde: DREAM ${ }^{20}$
Tabel 1 og 2 viser klart hovedudfordringen: Det faldende antal potentielt erhvervsaktive (15-64 årige) og det stærkt stigende antal ældre. Der er klare implikationer for forbruget af sundhedsydelser, der stiger med alderen. Der er naturligvis usikkerheder i prognoserne. De største usikkerheder kan indkredses til ændring i fertilitetsraten og dødeligheden og dermed middellevetiden.

Ideelt set ville man gerne fremskrive sygelighedsudviklingen. Eksempelvis stiger forekomsten af kroniske sygdomme med alderen. Der er omkring 1,1 millioner danskere med én eller flere kroniske sygdomme, fx astmaog allergilidelser eller muskel-skelet-sygdomme. Især gruppen med mere end én kronisk sygdom er en udfordring. Det er imidlertid ikke muligt at fremskrive sygelighedsudviklingen med stor sikkerhed, om end man kan udnytte historiske trends, fx for diabetes, hvis forekomst er stærk aldersafhængig. Derfor indgår sygelighedsudviklingen ikke i prognoserne, eller man opfatter middellevetid som en (meget ufuldstændig) proxy-variabel.

\section{De økonomiske konsekvenser af demografien}

I 2000 lavede Det Økonomiske Råd en første grov beregning af de økonomiske konsekvenser af befolkningsudviklingen, ${ }^{21}$ figur 1 . Man antog, at de aldersfordelte udgifter var uændrede fremover. Derfor skyldes udviklingen i af sundhedsudgifterne alene befolkningens størrelse og alderssammensætning.

Beregningerne viste, at sygehusudgifterne ville stige med 20 pct. og sygesikringsudgifterne knap 8 pct. de næste 40 år, hvis sundhedsudgifterne alene påvirkedes af den demografiske udvikling. Knap 6 procentpoint af stigningen i udgifterne skyldtes en stigning i den samlede befolkning.

I befolkningsprognosen var indbygget en antagelse om stigende middellevetid. Der sker imidlertid en overvurdering af det fremtidige udgiftspres, hvis man ikke medtænker, at en aldersgruppes sygehusudgifter falder, når deres restlevetid stiger, og færre derfor dør i den pågældende aldersgruppe. Det skyldes, at sygehusudgifterne er særlig høje ét til to år før man dør. Særskilte beregninger viste, ${ }^{22,} 23$ at stigningen i sygehusudgifterne blev 3 procentpoint lavere, når antagelsen om stigningen i middellevetiden og betydningen af 'tid til død' inddrages, det, der nedenfor kaldes 'sund aldring'. 
Figur 1: Prognose for udviklingen i sundhedsudgifter 2000-2040

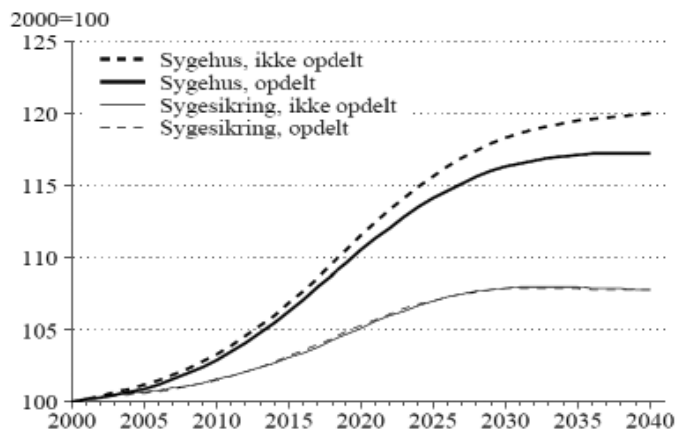

Anm.: Angivelsen "opdelt" markerer, at der i beregningen er taget højde for, at middellevetiden stiger i befolkningsprognosen.

\section{'Sund aldring'}

'Sund aldring' drejer sig om, at en betydelig del af sundhedsudgifterne i de sidste leveår ikke afhænger af alderen, men af restlevetiden, ${ }^{24-26}$ tabel 2. Disse sundhedsudgifter betegnes 'terminaludgifter' og terminaludgifterne udskydes til en højere alder, når levetiden stiger, dvs. sund aldring, som er blevet den dominerende terminologi.

Figur 2 viser i stiliseret form aldersprofilen for forbrug af sundhedsydelser. Sund aldring og den ændrede levetid vises ved en grad af parallelforskydning af aldersprofilen.

Der har været stor metodisk debat om sund aldring, ${ }^{12}$, ${ }^{13,26-36}$ bl.a. fordi den delvist tog luften ud af dommedagsagtige profetier om markant stigende sundhedsudgifter på grund af en aldrende befolkning. Kernen er spørgsmålet om, hvor meget sund aldring med rimelighed kan antages at mildne de økonomiske konsekvenser af aldringen. De empiriske estimater heraf varierer meget. I dansk sammenhæng har det været anført, at presset reduceres med op til 50\%. ${ }^{24,26,37}$ Dette må dog ikke betragtes som definitivt, og den internationale debat er fortsat levende.

Beregninger fra Det Økonomiske Råd viser, at terminaludgifterne udgør en væsentlig del af de samlede sundhedsudgifter, og at dette giver sig udslag i faldende sundhedsudgifter for ældre, når levetiden forlænges sva-

\section{Figur 2: Illustration af sund aldring ved forskydning af den aldersbestemte forbrugskurve for sundhedsydelser}

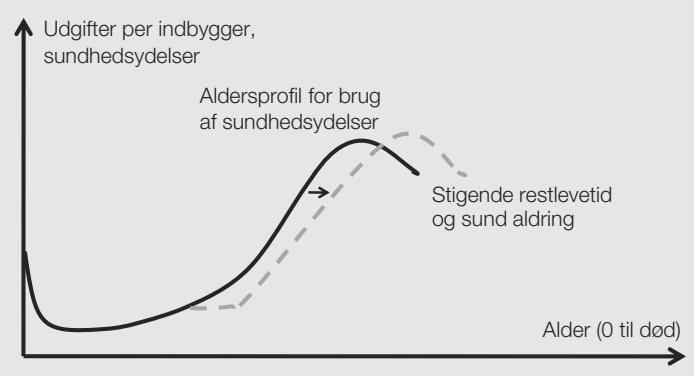

rende til sund aldring. Når der tages højde for sund aldring, halveres stigningen i de reale sundhedsudgifter som følge af forlængelser af levetiden sammenlignet med en beregning uden, ${ }^{24}$ jf. figur 3

\section{Figur 3: Usund aldring, sund aldring og udviklingen i middellevetiden 2008-2050}

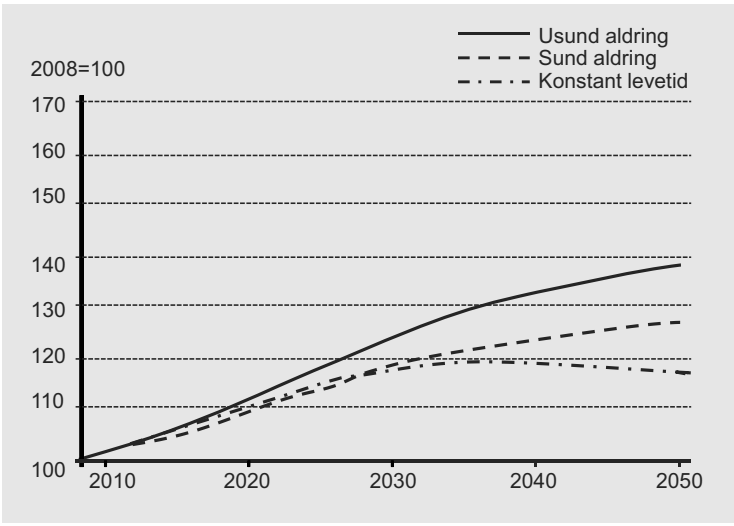

Kilde: Arnberg og Bjørner ${ }^{24}$. Beregninger foretaget med DREAM model og befolkningsfremskrivninger på baggrund af Arnberg og Bjorners estimationsresultater. Sundhedsudgifter opgjort i fast lonniveau (opgjort ved pris- og produktivitetskorrigerede offentlige sundhedsudgifter).

Med inddragelse af sund aldring og den almindelige demografiske udvikling kan en del af den fremtidige vækst $\mathrm{i}$ sundhedsudgifterne beregnes, men det forklarer ikke den samlede udgiftsudvikling. Derfor skal 'restvækstsen' også beregnes. Modelleringen heraf er relativt kompliceret og ikke uproblematisk.

\section{Restuaksten}

Man kan ikke lave holdbare prognoser uden at inddrage andre forhold ${ }^{38-40}$ end demografien, $\mathrm{fx}$ indkomst, den teknologiske udvikling og relative priser. ${ }^{41}$ I dansk sammenhæng er det løst ved at identificere, hvad der betegnes som mer-eller restvækst. I EU-prognoserne forsøger man at arbejde med bl.a. indkomstselasticitet. ${ }^{10}$

Ved restvækst forstås derfor den del af væksten i sundhedsudgifterne som ikke kan henføres til demografien, inkl. sund aldring.

Det Økonomiske Råd ${ }^{42}$ har beregnet, at ud af en årlig realvækst i sundhedsudgifterne på 2,4 pct. årligt i perioden 1993-2008, kan omkring 2,0 pct. point tilskrives ikke-demografiske forhold. Således udgør det demografiske vækstbidrag, når der tages højde for sund aldring, mindre end 20 pct. Indregnes effekten fra sund aldring ikke, vil betydningen af det ikke-demografiske bidrag reduceres til 1,8 pct. point. Udeladelse af effekten af sund aldring afstedkommer således en ikke ubetydelig over- 
vurdering af det historiske demografiske vækstbidrag, jf. ovenfor.

Restvæksten - i prognoserne kaldet mervæksten dækker bl.a. over behandlingsmæssige fremskridt ('teknologi'), politisk prioritering af området m.m..

Når der i det foregående og efterfølgende tales om sundhedsudgifter, skal det bemærkes, at det ikke er i OECD's forstand. OECD's sundhedsdata omfatter en samlet opgørelse over udgiften til sundhed og delvist ældrepleje, hvor en andel af sidstnævnte hos Danmarks Statistik indregnes under social omsorg. For praktiske forhold betyder det, at en af kommunernes sundhedsudgifter ikke indgår.

\section{Finanspolitisk holdbarhed}

Økonomien i et skattefinansieret sundhedsvæsen skal ses i sammenhæng med udviklingen i den offentlige sektors $ø$ konomi og de makroøkonomiske konjunkturer. Sundhedssektorens økonomi kan ikke adskilles fra den samlede økonomi.

I et skattefinansieret sundhedsvæsen bliver virkningen af niveau og vækst i sundhedsudgifterne på de offentlige finanser i prognosesammenhæng indfanget ved at se på finanspolitisk holdbarhed. Kort fortalt drejer finanspolitisk holdbarhed sig om balancen mellem (fremtidige) offentlige indtægter og udgifter - og holdbarhed er lig med, at der er balance. Mere teknisk siger man, at en given finanspolitik er holdbar, hvis den indebærer, at den offentlige sektor overholder sin langsigtede (intertemporale) budgetbetingelse. Det svarer til, at den tilbagediskonterede værdi af alle fremtidige primære budgetoverskud (dvs. overskud bortset fra renter) skal være lig med den offentlige gæld i udgangspunktet: På denne måde indfanges på én og samme gang såvel finansieringen (indtægter) som de ventede konsekvenser af demografi og øget velstand (udgifter). Hvis holdbarhedsindikatoren er nul, betyder det, at den langsigtede finanspolitik er holdbar i den forstand, at den offentlige sektors indtægter er store nok til at dække udgifterne.

Holdbarhedsproblemet måler man normalt i procent af BNP. Holdbarhedsindikator er den andel af BNP, som den offentlige sektor skal modtage årligt, for at der er holdbarhed på langt sigt.

\section{Det samlede resultat af prognosearbejdet}

Det Økonomiske Råds beregning i 2008 viste, at frem mod 2050 bliver den samlede vækst i sundhedsudgifterne i alt $42 \%$, når der tages højde for såvel mervækst- som levetidsforøgelses og årgangseffekter. Mervæksten er sat til 0,3\% per år, noget i underkanten af den historiske vækst, især i perioden 1999-2008.
Et alternativ, hvor der anvendes en mervækstrate på 0,6 pct.point for de ikke-demografiskbetingede sundhedsudgifter indebærer, at sundhedsudgifterne i 2050 er vokset med 60 pct. når der tages højde for alle tre effekter, jf. figur 4 .
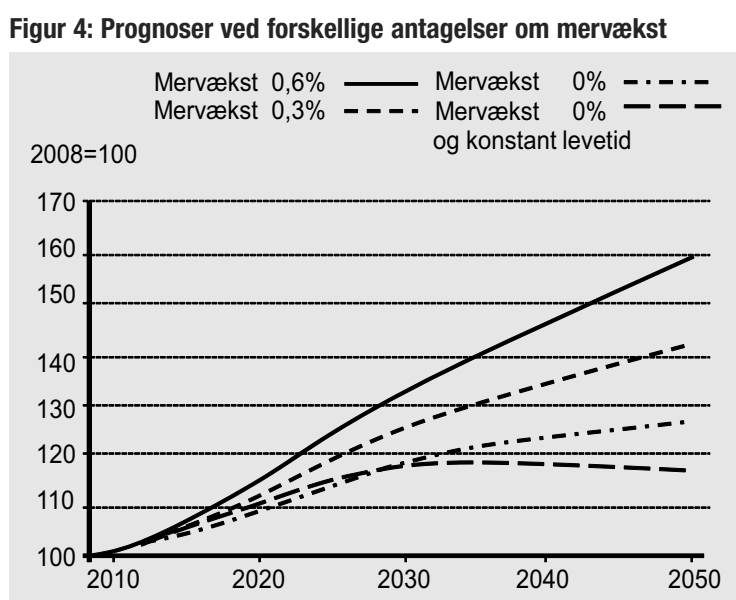

Kobles det foregående dernæst sammen med BNP for at danne sig et indtryk af den relative udfordring - i modsætning til den absolutte udfordring, som fremgår af figur 5, kræver det en prognose for væksten i BNP.

Udviklingen i BNP afhænger også af befolkningsudviklingen i det omfang, at denne fører til en ændring i arbejdsstyrken og dermed beskæftigelsen. Arbejdsstyrken vokser i takt med stigningen i levetiden af to grunde. For det første betyder den generelle tendens til lavere dødelighed og en antagelse om en uændret aldersbetinget erhvervsdeltagelse, at antallet af personer i arbejdsstyrken stiger. Hertil kommer, at stigningen i restlevetiden for 60-årige fører til stigninger i efterløns- og folkepensionsalderen fra 2025 og frem som en følge af velfærdsreformen. Disse reguleringer forventes at medføre stigninger i tilbagetrækningsalderen og dermed også stigninger i arbejdsstyrken.

Væksten i arbejdsstyrken i prognoseperioden kombineret med stigninger i levetiden indebærer for konstant strukturel ledighedsprocent, at produktionen målt ved BNP også vokser hurtigere end i alternativet med uændret levetid. Det betyder, at stigningen i sundhedsudgifterne i forløbene med voksende restlevetid i mindre grad giver anledning til et stigende udgiftstryk målt som udgifternes andel af BNP, jf. figur 5.

\section{DREAM-prognosen 2011}

Der offentliggøres løbende langtidsprognoser for dansk økonomi baseret på DREAM-systemet. Det består af 
Figur 5: Den økonomiske udfordring som pct. af BNP

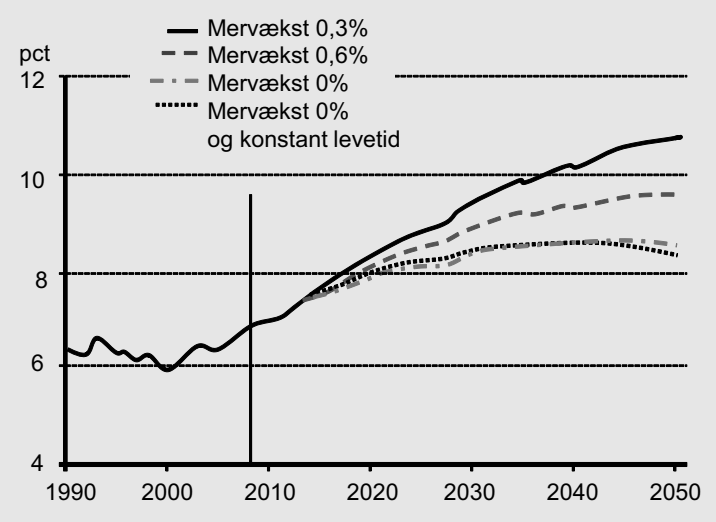

Kilde: Det økonomiske Råd/Hansen og Pedersen ${ }^{42}$

en befolkningsfremskrivning, en uddannelsesfremskrivning, et befolkningsregnskab og en økonomi-model. I 2011-fremskrivningen indgår en komponent for sundhedsudgifterne, der medtager såvel sund aldring som 'restvækst' (mervækst). DREAM-prognosen er ikke en eksakt forudsigelse af makroøkonomien på langt sigt, men mere en samlet vurdering af den offentlige sektors position i samfundsøkonomien på sigt. Dermed kan sundhedsudgifternes udvikling ses i sammenhæng med udviklingen i hele den offentlige sektor, hvilket sjældent er tilfældet, men særdeles relevant på grund af skattefinansieringen.

Ud fra DREAM-prognoserne beregner man holdbarhedsindikatoren og danner sig herved et overordnet billede af, hvor meget der skal forbedres i den offentlige sektors økonomi, og hvor meget sundhedsudgifterne udgør af holdbarhedsudfordringen.

Resultatet af DREAM-beregningerne fremgår af tabel 3. Beregningerne vedr. sundhedsudgifterne er baseret på antagelserne i Det økonomiske Råds beregninger, ${ }^{24,42}$ dvs. antagelser vedr. sund aldring og mervækst $(0,3 \%)$, ligesom der også er skelet til Finansministeriets beregninger fra 2007. ${ }^{37}$

DREAM-beregningerne er sammenkoblet med den $ø$ konomiske krise i den forstand, at de sættes i relation til udviklingen i bruttonationalproduktet, og udviklingen heri opsamler effekten af krisen og forskellige finanspolitiske tiltag.

DREAM-analysen viser, at finanspolitikken ikke er holdbar. Mens de offentlige indtægter som andel af BNP falder på lang sigt, forventes de samlede offentlige udgifter at vokse hurtigere end BNP. Det skyldes især væksten i udgifter til sundhed og social omsorg. De offentlige indtægter falder fra $2010 \mathrm{og}$ frem mod 2050 med et beløb svarende til cirka $0,8 \%$ af BNP, hvilket hovedsageligt skyldes et forventet fald i indtægter fra Nordsøen.

Den finanspolitiske holdbarhedsindikator er på -1,1 pct. af BNP. Det betyder, at den offentlige sektor har et finansieringsbehov svarende til 1,1 procent af løbende BNP hvert år i al fremtid.

Uden inddragelse af sund aldrings-antagelsen ville indikatoren have været på 1,2 pct. point højere, dvs. på $2,3 \%$, hvilket understreger sundhedsudgifternes centrale rolle og behovet for kritiske vurderinger af antagelserne om sund aldring.

Der er i 2011-beregningerne indlagt en mervækst i udgifter til sundhed og ældrepleje på 0,3 \% p.a. i 25 år

Tabel 3: Den samlede offentlige økonomi 2010-2040

\begin{tabular}{|l|c|c|c|c|c|c|c|}
\hline & $\mathbf{2 0 0 8}$ & $\mathbf{2 0 1 0}$ & $\mathbf{2 0 1 5}$ & $\mathbf{2 0 2 0}$ & $\mathbf{2 0 2 5}$ & $\mathbf{2 0 3 0}$ & $\mathbf{2 0 4 0}$ \\
\hline BNP, mia. kr. faste priser & 1714,5 & 1681,9 & 1826,6 & 2117,0 & 2667,4 & 3033,9 & $\mathbf{4 9 0 2 , 8}$ \\
\hline Offentlige indtægter, \% af BNP & 52,3 & 52,3 & 51,8 & 51,7 & 52,1 & 51,9 & 51,8 \\
\hline * direkte skatter, \% BNP & 30,5 & 27 & 28,9 & 29,6 & 29 & 28,8 & 28,7 \\
\hline * indirekte skatter, \% BNP & 17 & 16,9 & 17,3 & 17,6 & 17,8 & 17,7 & 17,6 \\
\hline Offentlige udgifter, \% af BNP & 50,2 & 55,1 & 51,3 & 52,4 & 53,2 & 53,8 & 54,2 \\
\hline * kollektivt forbrug, \% BNP & 7,8 & 9 & 8,3 & 8,4 & 8,4 & 8,4 & 8,4 \\
\hline * individuelt forbrug, \% BNP & 19,4 & 20,6 & 19,2 & 19,6 & 20,1 & 20,7 & 21,7 \\
\hline ** sundhedsudgifter, \%BNP & 7,1 & 7,8 & 8 & 8,5 & 8,9 & 9,3 & 10 \\
\hline ** social omsorg, \% BNP & 6,2 & 6,5 & 5,7 & 5,8 & 5,9 & 6,1 & 6,3 \\
\hline * indkomstoverførsler, \% BNP & 16,1 & 17,1 & 16,4 & 17,4 & 17,1 & 17,1 & 16,6 \\
\hline Offentlige nettorenteudgifter, \% BNP & $-0,2$ & $-0,1$ & 0,5 & 0,6 & 0,8 & 1,3 & 2,6 \\
\hline Offentlig budgetoverskud, \% BNP & 2,2 & $-2,8$ & 0 & $-1,3$ & $-1,9$ & $-3,2$ & -5 \\
\hline
\end{tabular}

Kilde: Uddrag af tabel 6.3 i DREAM ${ }^{19}$. BNP-beløbene beregnet ud fra tabel. 6.1 i DREAM-rapporten 


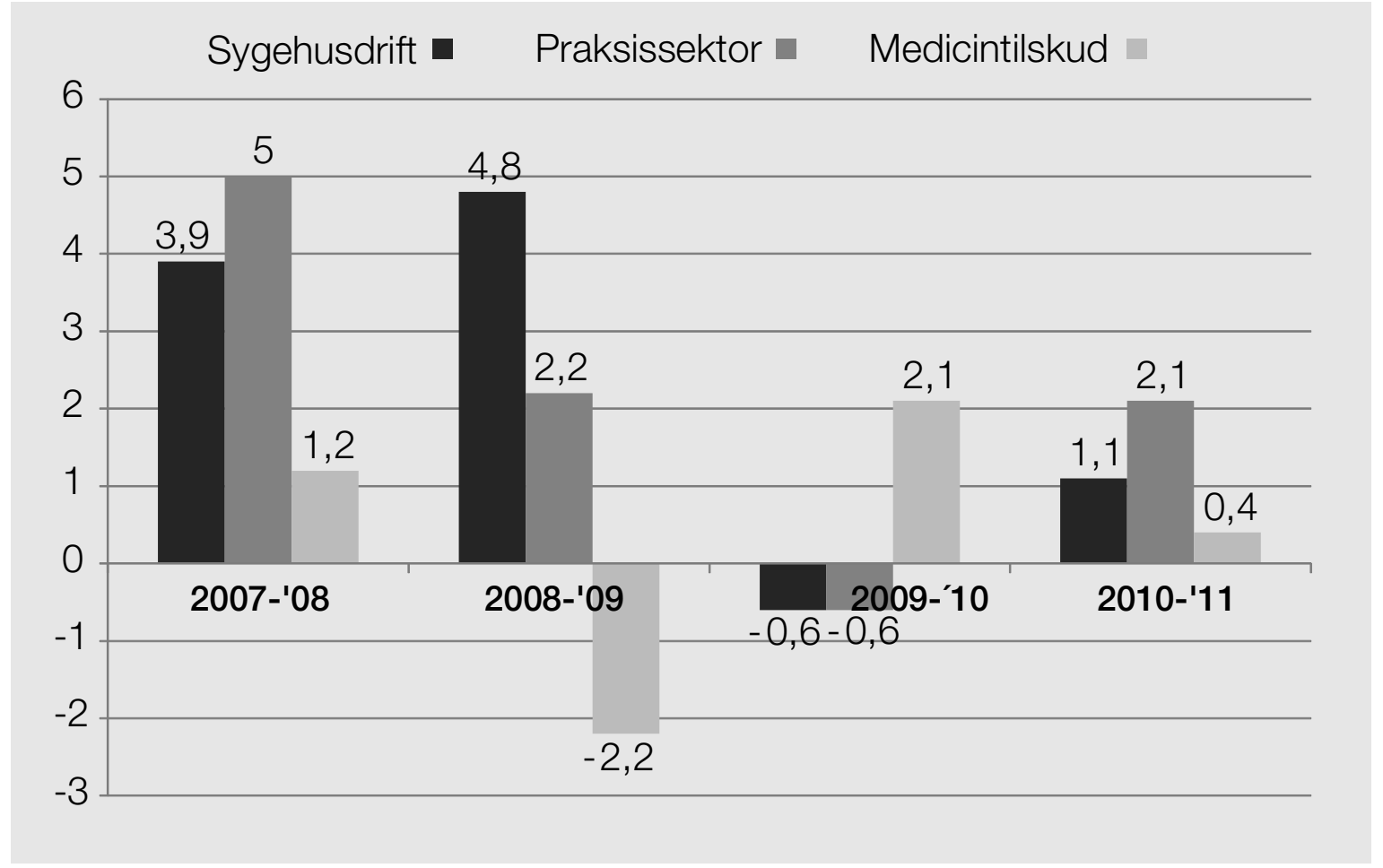

Kilde: Danske Regioner

fra 2014. Dette giver en forværring af holdbarheden på 0,7 pct. point.

Tilsammen giver beregningerne af de fremtidige sundhedsudgifter anledning til en nettoforbedring af holdbarheden på 0,5 pct. point sammenlignet med 2009-fremskrivningen (1,2-0,7). Sundhedsudgifterne spiller med andre ord en central rolle omkring fiskal holdbarhed.

Spørgsmålet er, om virkeligheden allerede har indhentet prognosen i tabel 3? Fx om antagelsen om 0,3\% mervækst per år ikke længere holder. Dette tages op i næste afsnit.

\section{Den økonomiske krise og sundhedsudgifterne}

Kort fortalt betyder den økonomiske krise, at sundhedsudgifternes reale vækstrate er blevet reduceret markant, figur 6 og 7, samtidig med, at demografien og den teknologiske udvikling fremadrettet kræver stigende ressourcer.

Fra 1999 til 2008 steg regionernes (amternes) sundhedsudgifter i gennemsnit med 3,3\% per år målt i faste priser $^{3}$. I økonomiaftalen for $2013^{43}$ er væksten på omkring 1\%, hvilket er det laveste i 20 år. I aftalen hedder det manende: 'Aftalen markerer en økonomisk prioritering af sundhedsområdet i 2013. Prioriteringen skal ses i sammenhæng med de aktuelt store underskud på de offentlige finanser og den økonomiske krise, der har skærpet kravene til finanspolitikken i Danmark.'

Overgangen fra en buldrende økonomi 2007-2008 til krisetider 2010-2011 fremgår tydeligt af figur 6

Figur 7 viser udviklingen i OECD, hvor man også ser en brat opbremsning 2009-2010. Krisereaktionen kommer hurtigt, hvis krisestarten sættes til 2008 med Lehman Brothers og Bear Sterns' konkurs.

Mere generelt finder man, at offentlige sundhedsudgifter falder i kølvandet på en økonomisk krise, ${ }^{44}$ men sjældent med den styrke som fremgår af figur 7, hvilket utvivlsomt skal ses i sammenhæng med krisens usædvanlige styrke og globale karakter. Omfang af omkostningsreduktioner - fra (meget) lav vækstrate til budgetreduktioner - afhænger stærkt af, hvor hårdt et land er ramt. Uden at det fremgår af figuren, kan det noteres, at forskellene mellem Italien, Spanien og UK (og landene i UK) er sigende illustrationer. ${ }^{45-47}$

VK-regeringens 2010-genopretningsplan ${ }^{4}$ gav beskeden vækst til 2 områder og nul- eller negativ vækst til øvrige områder i den offentlige sektor. Sundhedsområdet fik 5 mia. kr. fordelt over 2011-213 - og uddannelse m.m. fik ligeledes $5 \mathrm{mia}$. Det forhold, at der fortsat var vækst, men lavere end tidligere, viser sundhedsvæsenets særstilling illustreret ved, at den årlige realvækst i sundhedsvæ- 
Figur 7: Realvækst i offentlige sundhedsudgifter. OECD-landene sammenlignet med Danmark

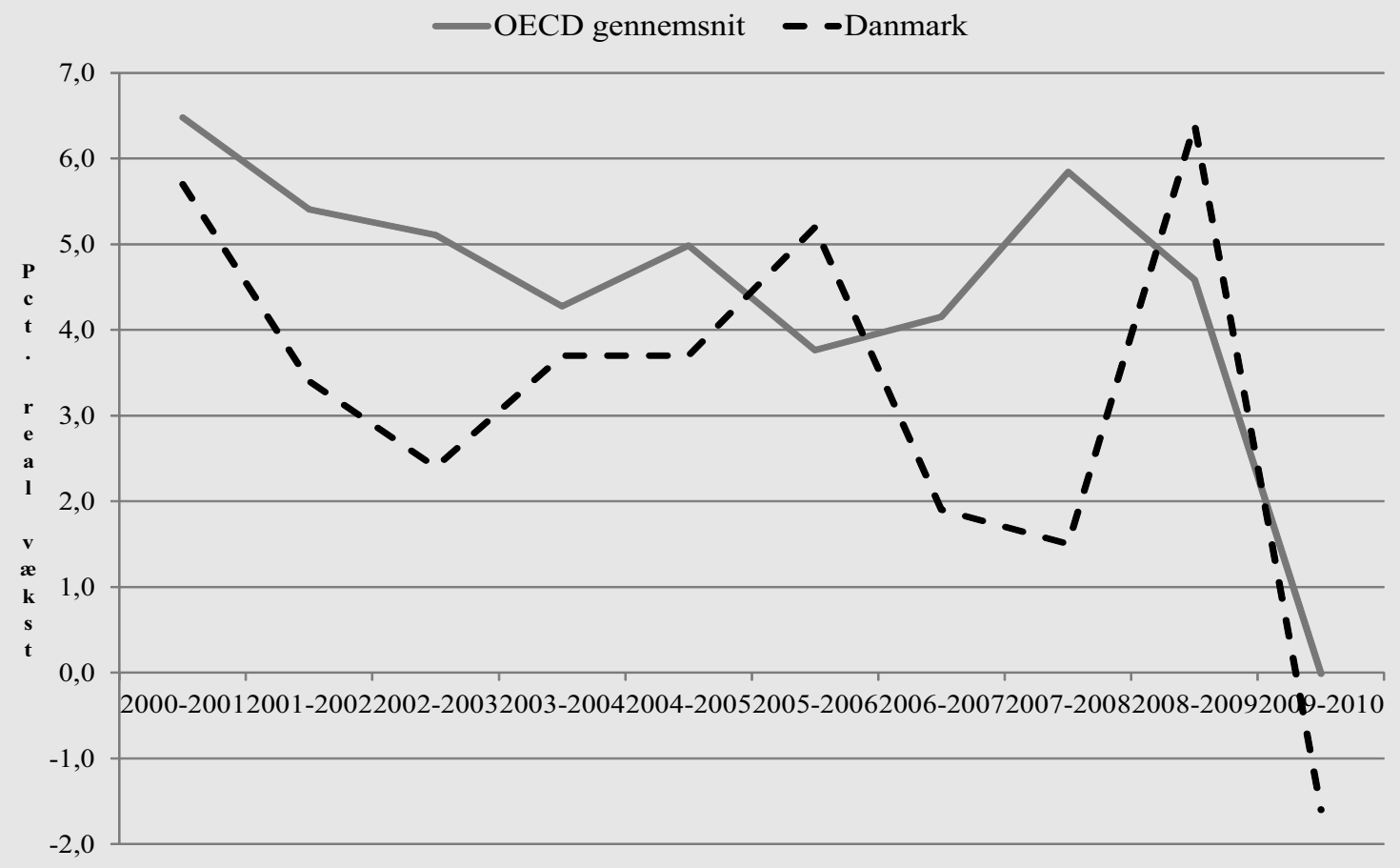

Kilde: OECD Health Data 2012, excl. Australien, Tyrkiet og Luxembourg. OECD-tallene medtager også kommunale sundhedsudgifter og dele af, hvad der i dansk statistik kaldes 'social', bl.a. dele af plejehjemsudgifterne, dvs. en anden udgiftsdefinition end i figur 6.

senet 2000-2009 har været markant højere end den årlige realvækst på 1,9\% i det samlede offentlig forbrug.

Thorning-Schmidt-regeringens „Danmark i arbejde Udfordringer for dansk økonomi mod $2020^{\text {“5 }}$ giver ikke sundhedsvæsenet en særstilling. Forudsat at de foreslåede reformer gennemføres, er der plads til en samlet årlig vækst på $0,8 \%$ i den offentlige sektor. Hertil kommer en prioriteringspulje på i alt 5 mia. frem mod 2020 - en pulje, som skal opbygges ved rationaliseringer m.m. altså ikke-eksisterende på plantidspunktet - og en anden pulje på 6 mia. til 'vækst, beskæftigelse, uddannelse, offentlig velfærd og grøn vækst'. Sundhedsvæsnet skal konkurrere med andre sektorer om disse i alt 11 mia. kr. svarende til godt 1,4 mia. per år.

Meget tyder på, at sundhedsvæsnets særstilling er under ændring. I bedste fald kan der måske blive tale om årlig vækst på 0,8-1,2 \% til at dække aldring, nye behandlinger m.m.. Hvortil kommer, at de offentlige finanser er afhængige af, om der kommer en vis økonomisk vækst. De økonomiske vismænd skønnede i forårsrapporten 2012, at man i 2012, 2013 og 2014 forudsagde en vækst i BNP på hhv. 1,3, 1,2 og 1,5 \%, og i DREAM-prognoserne frem mod 2050 er væksten i gennemsnit 1,6 \% p.a.
Sammenfattende betyder den økonomiske krise, at realvæksten i sundhedsudgifterne vil falde til i bedste fald $1 \%$ per år uanset politisk prioritering af sundhedsområdet.

\section{Strategier for den demografiske udfordring og den økonomiske krise}

Den aldrende befolkning og øget levetid fører til øgede fremtidige sundhedsudgifter: Fra 7,1 \% af BNP i 2010 til $10 \%$ i 2040 , hvis man skal tro prognosen i tabel 3. Den $ø$ konomiske krise giver lavere BNP-vækstrate og store statsfinansielle problemer svarende til, at realvæksten i sundhedsudgifterne falder fra godt $3 \%$ p.a. i det foregående tiår til i bedste fald 1\% i det kommende tiår. Samtidig går udviklingen af ny medicinske teknologi ikke i stå, men er dog i et vist omfang indregnet i prognoserne i kraft af 'mervækst', og befolkningens forventninger er fortsat høje. Det rejser naturligt spørgsmålet om, hvordan disse udfordringer kan håndteres - vel og mærke uden at det går ud over kerneværdier i sundhedsvæsenet som (næsten) fri og lige adgang for alle og (en rimelig) grad lighed.

Omsætter man de abstrakte procent-andele af BNP til kroner og ører, kan man ud fra tabel 3 beregne, at sundhedsvæsenet mellem 2010 og 2020 skal have tilført 
ca. 48 mia. kr., eller i gennemsnit omkring 4,8 mia. kr. om året. Det viser dog samtidig, at 'prognoser er prognoser' og sjældent er et stærkt grundlag for handling. Vi kan allerede i dag se, hvad der blev tilført sundhedsvæsenet i 2011, 2012 og 2013 under indtryk af Genopretningsplanen og Danmark i Arbejde. Med afsæt i økonomiaftalerne for de respektive år er der tilført sundhedsvæsenet $\mathrm{i}$ alt ca. 5-5,5 mia. ekstra i disse tre år. Prognose eller ej er ombremsningen allerede i gang. I forhold til prognoseforudsætningerne er det antagelsen om 0,3\% mervækst, der delvist er sat ud af kraft, fordi den på kort sigt lader sig påvirke politisk ved årlige budgetbeslutninger. Det samme gælder ikke for den demografiske udfordring.

Spørgsmålet bliver derfor, hvordan man skal formulere fremtidens økonomiske udfordring? Én måde vil være at formulere det som et spændingsforhold. Ser vi på perioden 2010-2020 viste prognosen et behov for omkring 48 mia. kroner, jf. tabel 3 - og det fiskalt holdbare økonomiske handlerum er ifølge Thorning-Smith-regeringen et sted mellem 0,8-1,2\% vækst per år. Regner man med en årlig vækst på $1 \%$, vil der kunne tilføres omkring 13-14 mia. kroner (med rentes rente) frem mod 2020. 'Spændingsforholdet' bliver derfor $48-14=34$ mia. kroner, som i forhold til prognosen kommer til at 'mangle'. En alternativ måde - der i realiteten ser bort fra prognoserne - er at spørge: Hvordan kan sundhedsvæsenet klare sig med en årlig vækstrate på $1 \%$ ?

\section{Løsningsstrategier}

Der findes ikke en sammenhængende strategi for løsningen af sundhedsvæsenets demografiske og krise-udfordringer. Forfatteren bekendt har der heller ikke været gjort forsøg på at udvikle en sådan. I det omfang der er strategier, vokser de gradvist frem i takt med, at udfordringerne skal konfronteres og via trial-and error. Det følgende er derfor en sammenstykning af, hvad der kan skimtes samt en række mere generelle overvejelser.

I det følgende ses der bort fra 'ønsketænknings-strategier a la 'folk vil gerne bruge mere på sundhedsvæsenet', 'det er jo en politisk prioritering, om vi vil bruge mere', 'i et rigt samfund spiller en vækstprocent ekstra ikke nogen rolle' osv. Udgangspunktet her er den kedelige økonomiske realitet, hvor fiskal holdbarhed og en samlet forståelse af den offentlige sektors økonomi og makroøkonomien er i centrum, jf. tabel 3, uden dog at tillægge prognoserne absolut sandhedsværdi.

Løsningstrategierne og behovet for dem afhænger af, om en ændret finansieringen af sundhedsvæsenet kan komme på tale, dvs. om ændret finansiering kan mindske den økonomiske klemme. ${ }^{48}$ Derfor undersøges dette først.

\section{Finansierings-situationen}

De økonomiske vismænd noterede i 2009 -analysen, ${ }^{3}$ at den forventede gradvise stigning i sundhedsudgifternes andel af BNP ville føre til et tilsvarende gradvist stigende offentligt finansieringsproblem, hvis sundhedsudgifterne også i fremtiden primært skulle skattefinansieres. De så korrekt kun tre muligheder og kombinationer heraf.

Den første mulighed består i, at andre offentlige udgiftsposter skal vokse langsommere end produktionen målt ved BNP. Dette er gøgeungemodellen, som har fungeret i flere år, jf. den almindelige offentlige udgiftsvækst sammenlignet med væksten i sundhedssektoren. Som tidligere nævnt er dette måske under delvis afvikling.

Eller, for det andet, skal skatteindtægterne vokse hurtigere end produktionen. En anden måde at udtrykke dette på er, at skattebyrden skal stige for at finansiere sundhedsvæsenet. De eksisterende politiske holdninger til dette peger på, at det næppe bliver en hovedløsning.

Den tredje mulighed er, at stigningen i sundhedsudgifterne finansieres ved brugerbetaling eller en form for privatisering af f.eks. visse typer af behandlinger, jf. hvad den forrige regering gjorde ved at belægge in vitro fertilisering med $100 \%$ brugerbetaling - et tiltag som den nuværende regering - formedelst 219 mio. kr. - ophævede med finansloven for 2012.

De seneste beregninger ${ }^{49}$ af provenueffekter for de offentlige kasser ved ret beskeden brugerbetaling for lægebesøg, skadestuebesøg, ambulant sygehusbehandling og sygehusindlæggelse viser et provenu på omkring 2,4 mia. kroner, hvortil kommer effekten af faldende efterspørgsel svarende til 0,7 mia. og 1,8 mia. kr. ved et fald på henholdsvis 10 og $25 \%$ for lægebesøg. Samlet svarer det imidlertid kun til én årlig stigning svarende til den gennemsnitlige årlige stigningstakt i 00'erne. Brugerbetaling er derfor ikke en løsning, der med et trylleslag løser alt.

Muligheden for at komme igennem med brugerbetaling - uanset at det findes i vores lige så lighedsorienterede nabolande - vurderes ikke som høj, om end den økonomiske virkelighed i det sidste års tid har ført til hidtil 'utænkelige' politiske indgreb.

Under vismændenes kategori 3 kan også medtages $ø$ get tegning af private sygeforsikringer. Om dette vil betyde noget, afhænger af to forhold: Om der som hidtil alene vil være tale om forsikringer for elektiv behandling, og om brugen af disse forsikringer i form af behandling på private sygehuse og klinikker i betydende grad aflaster det offentlige sundhedsvæsen, dvs. en reel substitution. Med hensyn til det første er det tvivlsomt, om der opstår et marked for forsikringer, der dækker akut behandling, dels på grund af størrelsen af den forventede præmie, dels fordi privathospitalerne radikalt skal ændre forretningsmodellen for elektiv behandling. Substitutions-virknin- 
Tabel 4: Løsningsmatrice: Finansiering og strategier.

\begin{tabular}{|l|l|l|l|}
\hline \multicolumn{1}{|c|}{ Finansieringen: } & $\begin{array}{l}\text { Tæt på nulvækst: 0-1 \%. } \\
\text { Det mest sandsynlige scenarie }\end{array}$ & $\begin{array}{l}\text { Nedskæring. } \\
\text { Sandsynlighed på 0,4-0,7 }\end{array}$ & $\begin{array}{l}\text { Endret finansiering } \\
\text { Sandsynlighed på under 0,5 }\end{array}$ \\
\hline Øget produktivitet & $\begin{array}{l}\text { Sandsynlighed: 0,9 } \\
\text { Påvirker ikke adgang og lighed }\end{array}$ & $\begin{array}{l}\text { Sandsynlighed:1 } \\
\text { Påvirker ikke adgang og } \\
\text { lighed }\end{array}$ & $\begin{array}{l}\text { Sandsynlighed: 0,9 } \\
\text { Påvirker ikke adgang og lighed }\end{array}$ \\
\hline Kvalitetsstrategien & $\begin{array}{l}\text { Sandsynlighed: 1. Kan margi- } \\
\text { nalt påvirke adgang og lighed } \\
\text { Hårdere prioritering: }\end{array}$ & $\begin{array}{l}\text { Sandsynlighed: 1. Kan margi- } \\
\text { nalt påvirke adgang og lighed }\end{array}$ & $\begin{array}{l}\text { Sandsynlighed: 0,9 afhænging af mer- } \\
\text { finanging. - Kan marginalt påvirke } \\
\text { adgang og lighed }\end{array}$ \\
\hline Kommune-region arbejdsfordelingen & & & \\
\hline Øget egenomsorg, forebyggelse og telemedicin & & & \\
\hline 'Reformer', herunder øget privatisering & & & \\
\hline Forventningsstyring: Færre løfter og garantier & & & \\
\hline
\end{tabular}

gen var meget beskeden i den eneste målrettede danske undersøgelser. ${ }^{50}$ Man skal her huske på, at forsikringsomsætningen ikke ligger meget over 1 mia. kr./å - og derfor i sagen natur ikke kan aflaste afgørende.

Tabel 4 kombinerer de økonomiske scenarier med en række omkostnings- eller efterspørgselsdæmpende tiltag samt 'reformer'. 'Ændret finansiering' i tabellens hoved dækker over det netop gennemgåede, medens scenariet med 0-1 \% vækst dækker regeringens 2020-plan, og 'nedskæring' er et værste case scenario, hvor sundhedsvæsenet bliver taber i spillet om det begrænsede økonomiske råderum. Der er indsat en meget grov sandsynlighedsvurdering af disse tre finansieringsmæssige muligheder. Sandsynligheden 1 markerer således forfatterens forventning om, at det er så godt som sikkert, at det vil ske. Reduceret vækstrate eller nedskæring er imidlertid næppe holdbare langtidsløsninger, men udtryk for, at man politisk naturligvis kan ændre vækstraten. Spørgsmålet er, om denne tilgang på længere sigt skubber et ophobet finansieringsbehov foran sig. Det grundlæggende spørgsmål bliver derfor, hvad man gør for at undgå, at opbygges et kumulativ økonomisk pres på grund af demografien og den teknologi. Det er her, nogle af strategierne i tabel 4 kommer i spil.

I cellerne i tabel 4 kan indsættes en forsigtig sandsynlighedsvurdering samt en meget grov vurdering af virkningen på adgangen til sundhedsydelser og lighed. Det er åbenbart, at effekten af tiltagene ikke blot skal vurderes i forhold til forventet økonomisk effekt men også i forhold til centrale sundhedspolitiske mål. Det er gjort illustrativt for et par af strategierne.

Ingen af strategierne kan isoleret løse udfordringerne. Nogle af strategierne er overlappende, fx produktivitet og kvalitet.

\section{Produktivitet}

Produktivitetsstrategien er allerede taget i brug. Spørgsmålet bliver derfor, hvor meget mere der kan opnås ad denne vej. I det sidste 10-år har økonomiaftalerne mellem regeringen og Danske Regioner (Amtsrådsforeningen) indeholdt krav om $2 \%$ produktivitetsforbedring. Bogholderimæssigt er det formuleret sådan, at man først reducerer aftalebeløbet med $2 \%$ og dernæst giver det tilbage sammen med et krav om mindst $2 \%$ aktivitetsvækst. Sygehusenes produktivitetsudvikling følges tæt med årlige rapporter. Den seneste rapport viste en produktivitetsforbedring på 5,6 \% fra 2009-2010 - en del over de foregående år. ${ }^{51}$ Produktivitetsforbedringer fremkommer via ibrugtagning af ny teknologi, fx ændrede operationsmetoder, arbejdsgangsanalyser, lean-processer m.m. ${ }^{12}$

Det er næppe realistisk at forvente vedvarende produktivitetsforbedringer af samme størrelsesorden - faktisk højere end i den private sektor. På den anden side er enhver produktivitetsforbedring - især på over $2 \%$ - et bidrag til mindskning af det økonomiske pres, fordi det er lig med en aktivitetsvækst, der bidrager til at mindske konsekvensen af den demografiske udfordring. Derfor vil der være et vedvarende pres for at øge produktiviteten over minimumstærsklen. Man skal her erindre, at der er indbyggede produktivitetskrav til de nye sygehusbyggerier frem mod 2020. Der er krav om en engangsgevinst $\mathrm{i}$ produktiviteten på mellem 6-8\% for hhv. større renoveringer og nybyggeri.

Produktivitetsforbedringer kan meget vel blive én af de største bidragsydere til håndtering af den simultane udfordring: Aldring og levetidsforlængelse kombineret en lav vækst i budgetterne, samtidig med at det ikke går ud over de centrale sundhedspolitiske mål om adgang og lighed. Arbejdet vil blive fulgt af vedvarende advarsler om, at det kan gå ud over kvaliteten - både den fagprofessionelle og patientoplevede. Erfaringer indtil nu peger dog ikke i denne retning. ${ }^{54}$ Det står også tilbage at få målt produktivitetsforbedringer i primærsektoren, inkl. den kommunale sundhedstjeneste, der ikke har været underlagt samme krav om produktivitetsforbedringer som sygehusene. 


\section{Kvalitet $i$ sundhed}

Danske regioner signalerede først i 2011 en ny dagsorden under overskriften 'Kvalitet i sundhed'.55 Den nye dagsorden er klar: 'Med udsigt til faldende eller stagnerende vækstrater, en demografisk udvikling med flere kronisk syge og ældre, muligheder for at behandle mere og flere og befolkningens stigende forventninger, kommer sundhedsvæsenet under et voldsomt pres. ... Regionerne ser bedre kvalitet som en væsentlig del af svaret på sundhedsvæsenets udfordringer. ${ }^{56}$ Dette er den klareste formulering af et forsøg på en egentlig strategi.

Som eksempel kan nævnes, at regionerne i 2012 har syv indsatsområder: Forebygge tryk/liggesår under indlæggelse, sikker kirurgi ved hjælp af simple tjeklister, hurtig diagnose og behandling af blodforgiftning, forebygge antibiotikaresistens, reducere forbruget af blod og fokus på, at RADS’ (Rådet for Anvendelse af Dyr Sygehusmedicin) anbefalinger på medicinområdet bliver efterlevet. Der er ikke tvivl om, at der er et betydeligt økonomisk potentiale på disse områder, ${ }^{57,58}$ samtidig med at den fagprofessionelle kvalitet forbedres. Måleteknisk vil disse gevinster blive indfanget af produktivitetsmålingerne.

Ud over det økonomiske budskab er et andet centralt budskab, at aktiviteten skal dæmpes (læs: Pengene rækker ikke): „Vi vil flytte ambitionerne fra at behandle mest muligt til at behandle bedst muligt, for kvalitet er ikke mere af det hele ... ,.. ${ }^{68}$ Man kan se dette som et forsøg på at italesætte en ny økonomisk virkelighed under en positiv ladet overskrift om kvalitet.

Kvalitetsstrategien udmærker sig ved ikke at være i grundlæggende konflikt med de centrale sundhedspolitisk mål.

\section{En ny prioriteringsmetode}

Behovet for prioritering har grundlæggende rod i misforholdet mellem tilrådighedværende ressourcer og ønsker. Med faldende eller negativ vækst skærpes den politiske prioritering erfaringsmæssigt: ${ }^{59}$ Det er svært at afgøre, hvor meget en skærpet prioritering vil bidrage til problemløsningen. Spørgsmålet er imidlertid, om tiden er kommet til at danne et nationalt prioriteringsinstitut svarende til det engelsk National Institute of Clinical Excellence, NICE, der har betydelig gennemslagskraft ${ }^{60}$ ved brug af økonomisk evaluering og behandlingsretningslinjer.

Prioritering drejer sig om at få pengene til at strække længere ved enten at fravælge eller hæve overliggeren for behandlingstilbud. Tendensen peger i øjeblikket mod at man hæver overliggen ${ }^{61}$ og dermed dæmper aktiviteten.

\section{Indikationsprioritering: En ny vakstdampende priorite- ringsmetode?}

Økonomiaftalen for $2012^{62}$ indeholdt et afsnit med overskriften 'Retningslinjer for visitation og henvisning'.
Uden at bruge ordet prioritering skrev man, at der skal opnås mest mulig sundhed for de samlede ressourcer, og at det er vigtigt at undgå utilsigtede skred i indikationer for behandling. Med andre ord: Hvordan kan man dæmpe aktivitetsvæksten og samtidig håndhæve et princip om, at offentligt finansieret behandling i sundhedsvæsenet skal være baseret på et fagligt funderet visitationsgrundlag. Hertil kommer, at prioriteringen ikke bliver ja eller nej til nye behandlinger, men drejer sig om justering af eksisterende behandlinger. Hvis det lykkes, udskyder man det den simple ja-nej-problemstilling, som prioritering ofte reduceres til.

Der blev allerede taget hul på problemstillingen med 2011-aftalen, ${ }^{63}$ hvor det blev aftalt, at man ville starte med fedme- og rygoperationer, fordi der havde været en kraftig aktivitetsvækst - især på privathospitalerne. Forventningen var at reducere antallet af fedmeoperationer med $40 \%$ og operationer på rygområdet med ca. $1 / 3 \mathrm{og}$ frigøre ressourcer til andre sundhedsydelser.

Virkningen har været mærkbar. Ifølge Danske Fedmekirurgiregister er antallet af fedmeoperationer faldet fra 4.383 i 2010 til 2.374 i 2011 , dvs. et fald på $46 \%{ }^{64}$ - svarende til en besparelse på omkring 200 mio. kr. For rygoperationer foreligger der kun oplysninger for første halvdel af 2011 sammenlignet med første halvdel af 2010. Antallet af operationer faldt fra 2110 til 1880 (DR internet nyheder d. 6. september 2011).

Ved tolkningen af tallene må man ikke være blind for, at den hævede overligger for behandling betyder, at færre kan bruge det udvidede frie sygehusvalg - og dermed også færre henvisninger til privathospitaler, som har været dominerende for fedmekirurgi og en betydende aktør for rygoperationer. Dette er utvivlsomt en væsentlig del af forklaringen på, at omsætningen på privathospitalerne faldt til ca. 750 mio. kr. i $2011 \bmod 1,2$ mia kr. 2010.65 Prioritering drejer sig jo både om at dæmpe udgiftsstigningerne eller få udgifterne til at falde. Umiddelbart ser indikationsprioritering ud til at virke, men vil det også være tilfældet, når det ikke længere rammer privathospitalerne? Dette er fortsat ubesvaret.

Det nye prioriteringsinstrument bliver derfor evidensbårne nationale kliniske retningslinjer, NKL, med det overordne formål kritisk at vurdere indikationer - og med en underforstået dagsorden om at skærpe indikationskriterierne og dermed sænke aktivitetsniveauet. På finansloven for 2012 er der afsat 25. mio. kroner til formålet. I Lægeforeningen ser man de kliniske retningslinjer som et egentligt prioriteringsredskab. ${ }^{67}$

\section{Kommunerne?}

Med strukturreformen 2007 fik kommunerne en stærkere placering på sundhedsområdet. Herunder også ordningen med kommunal medfinansiering for at give kom- 
munerne incitament til at intensivere det forebyggende arbejde - især for den patientrettede forebyggelse, der især drejer sig om kroniker-gruppen og de ældre.

Grundideen med den øgede involvering af kommunerne på sundhedsområdet var og er, at det samlet set skal give et billigere sundhedsvæsen uden at gå på kompromis med kvaliteten. Den centrale udfordring bliver at sikre, at der ikke i stedet bliver tale om en samlet udgiftsforøgelse, fordi kommunerne opruster uden at det giver sig udslag i mindre aktivitet i regionerne, især på sygehusene.

Det står forsat hen i det uvisse, om kommunerne effektivt kan medvirke til omkostningseffektivt at aflaste det regionale sundhedsvæsen. En ny midtvejsrapport ${ }^{69}$ om potentialet for forbedret kommunal forebyggelse peger på en række velkendte områder, fx forebyggelse af genindlæggelser. Det handler særligt om ældre medicinske patienter og visse kronikergrupper.

I den korte midtvejsrapport findes der ét af de velkendte hypotetiske regneeksempler, der har en tendens at gå fra at være hypotetisk til at blive fakta, når det gentages tilstrækkeligt mange gange: „Forskellen i kommunernes udgifter kan som beregningseksempel illustreres ved, at kommunernes udgifter til medfinansiering isoleret set ville være knap 800 mio. kr. lavere, hvis borgere i alle kommuner med et højere sundhedsforbrug pr. indbygger end kommunen med de 40. laveste medfinansieringsudgifter - standardiseret for køn og alder - fik nedbragt borgernes sundhedsforbrug (og dermed medfinansieringsudgifter) til dette niveau. En sådan reduktion i det regionale sundhedsforbrug ville alt andet lige beregningsteknisk indebære en reduktion af produktionsværdien i sygehusvæsenet og praksissektoren på samlet set omkring 3,2 mia. kr.", p. 2.

Eksemplet illustrerer et potentiale, men det skal underbygges med evidens fra velkontrollerede eksperimenter, hvor man kan belyse, om der findes omkostningseffektiv indsatser.

Der er ikke tvivl om, at en del af den demografiske udfordring skal løftes af kommunerne og regionerne i fællesskab. Det kniber fortsat - fem år efter strukturreformen - med at finde samarbejdsformer og forsøgsfællesskaber, der kan vise nye veje.

\section{Øget egenomsorg og telemedicin}

Øget ansvar for eget helbred og dermed øget egenomsorg er en central del af Sundhedsstyrelsens kronikerstrategi. ${ }^{70-71}$ Det er svært at vurdere det $ø$ konomiske potentiale og omkostnings-effektivitet. Desuagtet er det imidlertid en åbenbar og vigtig strategi, men det er ikke én, der afhjælper økonomiske problemstillinger her og nu, men på længere sigt.
Telemedicinske løsninger, fx hjemmemonitorering af kronikergrupper som KOL-patienter, sårpatienter og diabetikere, er lovende fremgangsmåder. ${ }^{72-75}$ Det centrale bliver, om de telemedicinske løsninger substituerer eksisterende sundhedsydelser og ikke blot bliver en forøgelse af serviceniveauet. I det sidste tilfælde bliver telemedicin en del af problemet, ikke løsningen. Veltilrettelagt forsøg skal understøtte evt. øget brug af telemedicin. Der er et betydeligt potentiale, men vi savner fortsat overbevisende evidens til at understøtte synspunktet.

\section{Reformer og oget privatisering}

Samlet set er det danske sundhedsvæsen velfungerende og sandsynligvis ret omkostningseffektivt. ${ }^{76}$ Der er således ikke tungtvejende årsager til at overveje grundlæggende reformer og slet ikke, fordi det vil løse fremtidige finansieringsproblemer. Den tidligere regering foreslog i 2011 at nedlægge regionerne. En nøgtern vurdering vil utvivlsomt føre til, at der ikke vil være mærkbare besparelser herved, når man betænker, at regionerne sandsynligvis ville blive erstattet af 3-4 statslige administrative enheder. Hertil kommer, at statslige sygehusvæsener i Norge og England heller ikke frister til efterligning. Den danske sygehusstruktur er blevet tilpasset i de senere år, og reformer vil næppe medføre ændringer i sygehusstrukturen, der økonomisk vil betyde ret meget.

"Privatisering" har to dimensioner: Finansiering (brugerbetaling, forsikringer), der er behandlet ovenfor, og produktion. Spørgsmålet er, om øget grad af udlicitering af $\mathrm{fx}$ elektive operationer til privat-sygehuse mærkbart vil føre til besparelser. Det centrale er 'mærkbart'. Der kan muligvis på kort sigt spares fx 100 mio. kroner ved øget udlicitering, men spørgsmålet er, om det er langtidsholdbare effekter, når privatmarkedet har stabiliseret sig. Foreliggende analyser, bl.a.fra CEPOS, peger ikke overbevisende i den retning. ${ }^{77}$

\section{Forventningsstyring - ferre garantier}

Behandlingsgarantier skal betrygge borgerne $\mathrm{i}$, at de kan forvente behandling inden for et rimeligt tidsrum, og dermed styrke tilliden til et skattefinansieret sundhedsvæsen, ligesom det også sætter sygehusvæsenet under et vist pres. For at virke overbevisende skal behandlingsgarantierne være udformet sådan, at de kan indløses andre steder end på offentlige sygehuse, hvis garantiperioden ikke opfyldes, dvs. i privatsektoren.

Én af bagsiderne ved garantierne er, at det indskrænker den økonomiske handlefrihed, fordi det er svært at trække garantier tilbage, selv i økonomisk hårde tider. Garantierne er $\mathrm{i}$ en vis forstand forhåndsfinansierede og låser dermed budgetterne. Fremadrettet bør man være 
særdeles forsigtig med at give flere garantier, medmindre man er villig til at (mer)finansiere dem.

I den politiske italesætning af sundhedsvæsenet skal politikerne forsøge at dæmpe befolkningens forventninger sådan, at de er afstemt med de økonomiske muligheder. Et eksempel herpå ser man ved Danske Regioners årlige Borgertopmøder, hvor man fx sidste gang havde prioritering på dagsordenen.

\section{Konklusioner og perspektiver}

Den dobbelte udfordring som sundhedsvæsenet står overfor i de næste 20-30 år er ikke uoverkommelige og behøver ikke at føre til dommedagsprofetier om det offentlige sundhedsvæsens endeligt, selvom antallet over 64-årige øges med 500.000 og antal 15-64 årige falder med 100.000. Det er især i tiden frem til 2020 med både $ø$ konomisk krise og demografisk pres, der bliver kompliceret at komme igennem.

Udfordringens størrelse ser man ved at sammenholde prognosernes årlige udgiftsstigninger på omkring 4,6 mia. kr. mod forventelige 1,3 mia. ved en vækstprocent på $1 \%$ i overensstemmelse med 2020-planen. Den $ø$ konomiske krise aftager forventeligt frem mod og efter 2020, medens den demografiske udfordring ikke topper før 2040-2050.

Internationalt indtager analyser af den demografiske udviklings betydning for fremtidens sundhedsudgifter og dermed for den offentlige sektors økonomi en stigende rolle, ${ }^{6-17}$ men det står dårligt til med strategier, ${ }^{78-80}$ og reelt set er der ikke megen hjælp at hente ved at studere tiltagene i andre lande, bl.a. fordi der er en tendens til at fokusere på nye finansieringsformer, som i lyset af den $ø$ konomiske krise må opfattes som strudsetaktik. Den danske strategi med at placere sundhedsvæsenet i den større kontekst, hvor spørgsmålet om fiskal holdbarhed adresseres eksplicit, medvirker til at vi i et vist omfang undgår strudsetaktikken. Der er grundlæggende behov for strategier, som 'accepterer' de økonomiske realiteter, bl.a. af den type, som fremgår af tabel 4 .

De skitserede danske strategier - især produktivitet incl. det ekstraordinære produktivitetskrav på grund af nye og renoverede sygehuse, kvalitet og prioritering - kan på kort sigt godt tackle lave vækstprocenter. På længere sigt kan der meget vel opstå problemer, fordi presset fra ny teknologi og forventninger, uanset forsøg på at dæmpe dem, vil føre til et pres, som kan være svært at holde inden for vækstrammer på 1-1,5 \% per år.

Historisk er der næppe tvivl om, at de lave vækstprocenter i 1980erne førte til, at vækstprocenterne i 1990erne nødvendigvis måtte blive højere - selvom det faldt sammen med en bedring af de makroøkonomiske forhold og udsagnet derfor ikke tolkes kausalt. De skitserede strategier skal utvivlsomt både styrkes og suppleres, hvis der efter 2020 fortsat er tale om vækstprocenter af den skitserede karakter.

\section{Litteraturliste}

1. Velfærdskommissionen. Fremtidens velfærd kommer ikke af sig selv. København: Velfærdskommissionen, 2006

2. Velfærdskommissionen. Befolkningsudvikling, velstandsdilemma og makroøkonomiske strategier. København: 2005.

3. Det økonomiske råd. Dansk Økonomi • Efterår 2009. Sundhed ). København: Det økonomiske Råd, 2009

4. Regeringen og Dansk Folkeparti. Aftale om genopretning af den danske økonomi. København: Finansministeriet, 2010

5. Regeringen. Danmark i arbejde. Udfordringer for dansk økonomi mod 2020. København: Finansministeriet, 2012

6. Bech M, Christiansen T, Khoman E, Lauridsen J, Weale M. Ageing and health care expenditure in EU-15. Eur J Health Econ 2011;12(5):469-478.

7. Breyer F, Costa-Font J, Felder S. Ageing, health, and health care. Oxford Review of Economic Policy 2010;26(4):674-690.

8. Breyer F, Felder S. Life expectancy and health care expenditures: a new calculation for Germany using the costs of dying. Health Policy 2006;75(2):178-186.

9. Christensen K, Doblhammer G, Rau R, Vaupel JW. Ageing populations: the challenges ahead. Lancet 2009;374(9696):1196-1208.

10. European Commission. The 2012 Ageing Report: Underlying Assumptions and Projection Methodologies. European Commission, 2011European Economy 4: 2011.)

11. European Commission. The 2012 Ageing Report Economic and budgetary projections for the 27 EU Member States (2010-2060). Bruxelles: European Commission, 2012European Economy 2.)

12. Hakkinen U, Martikainen P, Noro A, Nihtila E, Peltola M. Aging, health expenditure, proximity to death, and income in Finland. Health Econ Policy Law 2008;3(Pt 2):165-195.

13. Polder JJ, Barendregt JJ, van OH. Health care costs in the last year of life--the Dutch experience. Soc Sci Med 2006;63(7):1720-1731.

14. Regeringskansliet. The future need for care-Results from the LEV project. Stockholm: Regeringskansliet, 2010

15. Miller T, Mason C, Holz M. The Fiscal Impact of Demographic Change in Ten Latin American Countries: Projecting Public Expenditures in Education, Health, and Pensions. Washington, D.C.: World Bank; 2011.

16. Freund D, Smeeding TM. The Future Costs of Health Care in Ageing Societies: Is the Glass Half Full or Half Empty? International Studies in Population, vol. 8. New York and Heidelberg: Springer; 2010.

17. Meier V, Werding M. Ageing and the Welfare State: Securing Sustainability. Oxford Review of Economic Policy 2010;26(4):655673.

18. Astolfi R, Lorenzoni L, Oderkirk J. Informing policy makers about future health spending: A comparative analysis of forecasting methods in OECD countries. Health Policy 2012.

19. DREAM. Langsigtet økonomisk fremskrivning 2011. København: DREAM, 2011

20. Hansen M, Stephsen P. Danmarks fremtidige befolkning. Befolkningsfremskrivning 2011. København: DREAM, 2011

21. Det økonmiske Råd. Dansk Økonomi forår 2000. København: Det økonomiske Råd, 2000

22. Madsen J, Serup-Hansen N, Kragstrup J, Kristiansen IS. Ageing may have limited impact on future costs of primary care providers. Scand J Prim Health Care 2002;20(3):169-173. 
23. Madsen J, Serup-Hansen N, Kristiansen IS. Future health care costs--do health care costs during the last year of life matter? Health Policy 2002;62(2):161-172.

24. Arnberg S, Bjørner TB. Sundhedsudgifter og levetid. National Økonomisk Tidsskrift 2010;148(1):43-66.

25. Pedersen LH, Hansen M. Stigende sundhedsudgifter, et aldrings- eller et velstandsfænomen? Nationaløkonomisk Tidsskrift 2006;144:304-325.

26. Bjorner TB, Arnberg S. Terminal costs, improved life expectancy and future public health expenditure. Int J Health Care Finance Econ 2012;12(2):129-143.

27. Felder S, Werblow A, Zweifel P. Do red herrings swim in circles? Controlling for the endogeneity of time to death. J Health Econ 2010;29(2):205-212.

28. Salas C, Raftery JP. Econometric issues in testing the age neutrality of health care expenditure. Health Econ 2001;10(7):669-671.

29. Seshamani M, Gray A. Ageing and health-care expenditure: the red herring argument revisited. Health Econ 2004;13(4):303-314.

30. Seshamani M, Gray A. Time to death and health expenditure: an improved model for the impact of demographic change on health care costs. Age Ageing 2004;33(6):556-561.

31. Werblow A, Felder S, Zweifel P. Population ageing and health care expenditure: a school of 'red herrings'? Health Econ 2007;16(10):1109-1126.

32. Zweifel P, Felder S, Meiers M. Ageing of population and health care expenditure: a red herring? Health Econ 1999;8(6):485-496.

33. Colombier C, Weber W. Projecting health-care expenditure for Switzerland: further evidence against the 'red-herring' hypothesis. Int J Health Plann Manage 2011;26(3):246-263.

34. Stearns SC, Norton EC. Time to include time to death? The future of health care expenditure predictions. Health Econ 2004;13(4):315-327.

35. Wong A, Wouterse B, Slobbe LC, Boshuizen HC, Polder JJ. Medical innovation and age-specific trends in health care utilization: findings and implications. Soc Sci Med 2012;74(2):263-272.

36. Wouterse B, Meijboom BR, Polder JJ. The relationship between baseline health and longitudinal costs of hospital use. Health Econ 2011;20(8):985-1008.

37. Finansministeriet. Mod nye mål - Danmark 2015. Teknisk baggrundsrapport. København: Finansministeriet, 2007

38. Martin JJM, Lopez del Amo Gonzalez MP, Garcia MDC. Review of the Literature on the Determinants of Healthcare Expenditure. Applied Economics 2011;43(1-3):19-46.

39. Herwartz H, Theilen B. The Determinants of Health-Care Expenditure: New Results from Semiparametric Estimation. Health Economics 2010;19(8):964-978.

40. Gerdtham U-G, Jönsson B. International comparisons of health expenditures. In: Culyer A, Newhouse J, editors. Handbook of Health Economics. Amsterdam: North Holland; 2000:11-53.

41. van Elk R, Mot E, Franses P. Modeling healthcare expenditures: overview of the literature and evidence from a panel time-series model. Expert Review of Pharmacoeconomics \& Outcomes Research 2010;10(1):25-35.

42. Hansen MF, Pedersen LH. Sundhedsudgifter og finanspolitisk holdbarhed. Nationaløkonomisk Tidsskrift 2010;148(3):21-42.

43. Regeringen, Danske Regioner. Aftale om regionernes økonomi for 2013. København: Finansministeriet, 2012

44. Cylus J, Mladovsky P, McKee M. Is There a Statistical Relationship between Economic Crises and Changes in Government Health Expenditure Growth? An Analysis of Twenty-Four European Countries. Health Serv Res 2012 47(3): 1-21.

45. Appleby J. What's happening to NHS spending across the UK? BMJ 2011;342:d2982.
46. de Belvis AG, Ferre F, Specchia ML, Valerio L, Fattore G, Ricciardi W. The financial crisis in Italy: Implications for the healthcare sector. Health Policy 2012;106(1):10-16.

47. Gene-Badia J, Gallo P, Hernandez-Quevedo C, Garcia-Armesto S. Spanish health care cuts: Penny wise and pound foolish? Health Policy 2012;106(1):23-28.

48. Thomson S, Foubister T, Mossialos E. Financing health care in the European Union. Challenges and policy responses. København: European Observatory on health systems and policies, WHO, 2009Observatory series study no. 17.)

49. Kiil A, Houlberg K. Adfærdsmæssige effekter af brugerbetaling. En systematisk forskningsgennemgang af danske og internationale undersøgelser på sundheds- og ældreområdet fra 1990-2011. København: AKF, 2012

50. Søgaard R, Bech M, Olsen J. Effekten af private sundhedsforsikringer på forbruget af offentligt finansierede sygehusydelser. Odense: CAST, Syddansk Universitet, 2011CAST Rapport.)

51. Danske Regioner, Finansministeriet, Ministeriet for Sundhed og Forebyggelse. Løbende offentliggørelse af produktiviteten i sygehussektoren. VII delrapport. Udviklingen fra 2009 til 2010. København: Ministeriet for Sundhed og Forebyggelse, 2011

52. Baumol W, Bowen W. Performing Arts: The Economic Dilemma. New York: The Twentieth Century Fund.; 1966.

53. Baumol W, Bowen W. On the Performing Arts: The Anatomy of their Economic Problems. The American Economic Review 2012;55(2):495-502.

54. Mainz J, Bartels P, Bek T et al. Kvalitetsudvikling i praksis. København: Munksgaard; 2011.

55. Danske Regioner. Kvalitet i sundhed. København: Danske Regioner, 2011

56. Danske Regioner. Med kvalitet som ledestjerne. København: Danske Regioner, 2011

57. Pedersen K, Kolmos HJ. Hospitalinfektioners økonomi. Health Econmics Papers 2007:4 (www healtheconomics dk/publications/ working papers) 2007

58. Pedersen K, Kolmos H. Hospitalsinfektioner - en samfundsøkonomisk udfordring. Ugeskrift for Læger 2007;169(48):4135-4138.

59. Pedersen K. Sundhedspolitik. Beslutningsgrundlag, beslutningstagen og beslutninger i sundhedsvæsenet. Odense: Syddansk Universitetsforlag; 2005.

60. Pedersen K, Bech M, Vrangbæk K. The Danish Health Care System: An Analysis of Strengths, Weaknesses, Opportunities and Threats (SWOT analysis). Odense: Research Unit of Health Economics, 2011Health Economics Papers 2011: 2.)

61. Pedersen K. Prioritering - objektive prioriteringskriterier. Tidsskrift for Dansk Sundhedsvæsen 2012;88(4):16-20.

62. Finansministeriet. Aftaler om den kommunale og regionale økonomi for 2012. 2012.

63. Finansministeriet. Aftaler om den kommunale og regionale økonomi for 2011. København: Finansministriet; 2010.

64. Heissel A. Antallet af fedmeoperationer er faldet til det halve. Dagens medicin (netudgave) 2012.

65. Sundhedsministeriet. Udvikling i takster og udgifter for det offentlige ved køb af sygehusydelser på private sygehuse. København: Ministeriet for Sundhed og Forebyggelse, 2012

66. Sundhedsministeriet. Retningslinjer for visitation og henvisninger for degenerative lidelser i columna. 2010. Københav, Sundhedsministeriet.

67. Dall M. Nationale kliniske retningslinjer set med Lægeforeningens øjne. (oplæg ved medlemsmøde i Lægeforeningen Syddanmark). 2011.

68. Danske Regioner. Kvalitet i sundhed. København: Danske Regioner, 2011 
69. Danske Regioner, KL, Ministeriet for Sundhed og Forebyggelse, Finansministeriet, Økonomi-og indenrigsministeriet. Status for udvalgsarbejdet vedr. potentiale for forbedret kommunal forebyggelse. Foreløbig afrapportering. Juni 2012. København: Ministeriet for Sundhed og Forebyggelse, 2012

70. Sundhedssstyrelsen. Egenomsorg. Et særligt perspektiv på forebyggelse og sundhedsfremme. København: Sundhedsstyrelsen; 2006.

71. Sundhedsstyrelsen. Kronisk Sygdom. Patient, sundhedsvæsen og samfund. 2005.

72. Afdelingen for Kommunesamarbejde. Telemedicinsk understøttelse af behandlingen af sårpatienter - en mini-MTV vedrørende telemedicin og sårbehandling i Sønderjylland. Vejle: Region Syddanmark, 2009

73. Ekeland AG, Bowes A, Flottorp S. Effectiveness of telemedicine: A systematic review of reviews. International Journal of Medical Informatics 2010;79(11):736-771.

74. Steventon A, Bardsley M, Billings J et al. Effect of telehealth on use of secondary care and mortality: findings from the Whole System Demonstrator cluster randomised trial. BMJ 2012;344:e3874.

75. Teknologisk Institut. Analyse af samfundsøkonomiske effekter ved båndbredskrævende telemedicin. 2008.

76. Pedersen K. Prioritering - objektive prioriteringskriterier. Tidsskrift for Dansk Sundhedsvæsen 2012;88(4):16-20.
77. Holstein M. Regionernes udbud af sundhedsydelser. København: CEPOS, 2011

78. Mladovsky P, et al. Health Policy in the Financial Crisis. Eurohealth Observatory 2012;18(1):3-7.

79. Stuckler D, Basu S, Suhrcke M, Coutts A, McKee M. The public health effect of economic crises and alternative policy responses in Europe: an empirical analysis. Lancet 2009;374(9686):315-323.

80. Thomson S, Foubister T, Mossialos E. Financing health care in the European Union. Challenges and policy responses. København: European Observatory on health systems and policies, WHO, 2009Observatory series study no. 17 .

\section{Noter}

1 Produktiviteten på sygehusene modbeviser i en vis forstand Baumols teorier om lav produktivitetsvækst i arbejdsintensive serviceerhverv $^{52,53}$ - en hypotese, som de økonomiske vismænd overtog i rapporten om sundhedssektoren. ${ }^{3}$ Man skal her huske, at Baumols afsæt var symfoniorkestre m.m., hvor indførelse af ny teknologi har begrænset rækkevidde, medens det i høj grad er muligt på sygehuse. 